\title{
Regional Products With the Protection of Origin in Serbia Tourism Offer
}

Indonesian Journal of Tourism and Leisure, 2020
Vol. 01 (2), $61-72$
(C) The Journal, 2020
DOI: $10.36256 /$ ijtl.v1i2. 101
https: / /journal.lasigo.org/index.php/IJTL
Article History
Received: Augustus $30^{\text {th }}, 2020$
Revised: November $16^{\text {th }}, 2020$
Accepted: November $22^{\text {nd }}, 2020$
Vol. 01 (2), 61-72

C) The Journal, 2020

(ijtlv1i2.101

https://journal.lasigo.org/index.php/IJTL

\section{Miloš Ćirić}

Department of Hotel Management School, Academy of Vocational Studies, Belgrade, Serbia

Email: milos.ciric.gastronom@gmail.com

\section{Bojana Kalenjuk}

Department of Geography, Tourism and Hospitality, Faculty of Science, University of Novi Sad, Novi Sad, Serbia

Email: bojanakalenjuk@yahoo.com

\section{Ivana Janković}

High School of Tourism, New Belgrade, Serbia

Email: jankovic.ivanaaa@gmail.com

\begin{abstract}
The product protection system has been created in order to keeping up with the development of tourism and the need to offer and highlight unique agricultural, food, and gastronomic products. In this way, trademarks have positive effects on users of services or products, creating a clear picture of specific, authentic characteristics of food and beverages. Their constant production and sales have a positive impact on the economic development of the country - the region from which the products come. The paper has the task to showcase protected products by regions that can favorably affect the economic growth through sales and supply within catering and tourism facilities. This paper aims to consider the number, types, and characteristics of these products within the region, as important part of the gastronomic offer, tourist and economic development of the country. The research was conducted on the basis of appropriate documentation of data available to the Institute for the Intellectual Property of the Serbia. Based on the conducted research, it was concluded that in the territory of the Serbia, the region with the largest number of protected products is Vojvodina, while Šmadija is the region with the smallest number of protected products
\end{abstract}

Keywords: Tourism, Gastronomy, Regionalization, Protected Products, The Geographical Indication of Origin, Name of Origin.

\section{Introduction}

Primary production and adequate distribution of products as products of protected origin attract great attention as a very important factor that influence consumer behavior, in addition, this type of protection requires high quality products aimed at protection from unfair competition (Katerinopoulou et al., 2020). Geographical indications and designations of origin are products that originate in any region or can be attributed to any region because of their quality, reputation 
or other characteristics. A geographical indication provides information about raw materials, geographical roots of materials or final products to consumers and characterizes the degree of its quality (Ucuncuoglu, 2020).

The system of a geographical indication of food and beverages at the global level in the last decade is of great importance (Conneely \& Mahon, 2015; Danezis et al., 2016; Deselnicu et al., 2013; Roselli et al., 2018) in the economic development of individual countries, while in Serbia, intellectual property rights have gained in value only in the last few years (Zarić et al., 2012). What is important to emphasize is that the laws in Serbia in this area are in the highest percentage harmonized with the international one (Bojana et al., 2014). Products of protected origin can be defined as products whose quality can be attributed to the region they come from and labeled to be recognized as traditional and authentic products (Neciunskas et al., 2017). Such products are sold at significantly higher prices, and thanks to their unique characteristics, they are easier and better sold compared to other products. They attract customers/tourists by presenting them as superior, raising their awareness of the top quality or special characteristics that such products usually have (Dogan \& Gokovali, 2012; Tešanović \& Koprivica, 2007). The geographical indication of the product gives a chance for economic development and an increase of GDP through placement on the domestic and foreign markets and through consumption by the local population and tourists who are looking for unique gastronomic experiences that such products have. Out of the total number of protected products in the world, $85 \%$ of products relate to agri-food products (Marina et al., 2016). Traditional farming and cultivation of certain products in certain areas has led to the emergence of possible national brands (Prokopović \& Prokopović, 2011). According to the data from the Intellectual Property Office in 2020, the list of Serbia includes 65 domestic products with a protected name of the origin or geographical indication. It is the production and placement of such products on the tourist market that can influence the development of underdeveloped regions in the country (Banjac et al., 2012).

The subject of this paper are products with a designation of origin in the territory of Serbia as important factors of catering and tourism economy. The task of the paper is to answer the following research question: Which products and to what extent are protected in the regions of Serbia? The paper aims to present the protected products in the regions of the country that favorably contribute to economic development through sales and consumption in catering and tourism.

\section{Literature Review}

The growing dissatisfaction of food consumers from industrial production is increasingly highlighted in the literature. Their health concerns and desire to support local producers led them to look for other alternatives: products that are local, traditional and region-specific, such as food products with a geographical indication (Fernández-Ferrín et al., 2019). Products with a designation of origin, as unique and specific products from the aspect of production and quality, represent an important agricultural and food factor. By labeling products, the qualities of products are declared, which originate from a certain region, where various factors affect the specificity, characteristics, and ultimately the reputation of these products (Dogan \& Gokovali, 2012). A geographical indication is the name of a place, region, or country that identifies a product whose quality, reputation, and other characteristics may be associated with the place of origin. It also suggests to consumers that a particular good has characteristic particularities which are such because of the place of origin of that product. Thus confirms that a geographical indication is more than a designation of origin, which indicates only the origin of the product and not certain qualities (Cei et al., 2018; Lombardo, 2015; Oliinyk et al., 2018; Vandecandelaere et al., 2010; Wilson et al., 2018).

Geographical indications indicate the name of a region, a specific location or, for example, in exceptional cases, the country of production, as such the product should have a unique specific 
quality, method of preparation and reputation that can be linked to other characteristics related to geographical origin and caused by natural factors like climate, landscape, fauna and flora, production methods and traditions (Brown \& Paszkiewicz, 2017; Santeramo et al., 2018). Geographical indications of origin play a significant role in fostering rural climates (Cei et al., 2018). The system of protection of geographical indications is a very important tool for the development and popularization of the region, especially rural areas, which gives a chance to producers of traditional products to brand their products and increase competitiveness by using this protection (Anton et al., 2016) which contributes to sales in the tourism market (Banjac et al., 2012).

It should be emphasized that a very important fact in the production of products with protected origin are the multiple economic benefits of such products which are used as part of the marketing strategy of the country or region because many consumers appreciate local specialties, which certainly has a positive effect on economic growth (Firdaus, 2018; Marina et al., 2016). Also, what is especially important by using products with a designation of origin internationally, consumers create an image and opinion about the country from which the product comes (Cairns, 2013).

The protection system of products of geographical origin is directly related to the preservation of local plant varieties, the monetary reward of the local population and the sustainable development of rural areas (Likoudis et al., 2016). Bryła (2017) in her research states that consumers who attach importance to product quality are more likely to buy food with a labeled origin than those who feel that this characteristic is not important. Consumers want to buy products with the protected origin, compared to conventional products (Agostino \& Trivieri, 2014). Indigenous products are food products that due to technological, nutritional and organoleptic specifics, quality and uniqueness can successfully become part of the gastronomic offer of a particular country. The most important reasons for the protection of indigenous products include: protection against misuse of the original product, achieving a higher price category of products, increasing income for producers, contributing to sustainable rural development, strengthening tourism offer, increasing consumer demand for indigenous products, preserving tradition of local, regional and national identity, preventing the outflow of population from rural areas (Jurinčič et al., 2015).

The link between sustainability and geographical indication is multiple. Based on several case studies that have shown that products with geographical protection of origin can be considered as drivers of sustainable and rural development (Chilla et al., 2020). In particular, food tourism refers to the discovery of culture through food (Long, 2004). In this sense, gastronomic tourism is therefore based on the concept of knowledge and learning, tasting and enjoying the gastronomic culture that is identified with the territory (Fusté-Forné, 2020). Food tourism represents visits to food producers, food fairs and gastro festivals, events, markets or other food-based tourism activities (Hall \& Sharples, 2003), while based on (Word Tourism Organization UNWTO, 2012) it is emphasized that food tourism allows visitors to discover the region's heritage through tasting, experiencing and buying food products. In the respect of gastronomy, gastronomic tourism is a key tool for local and regional development (Baldacchino, 2015). As per the UNWTO (2019) which says that during the last decades gastronomic tourism goes far beyond the classic frameworks such as consuming food in a restaurant, it now includes all food sectors in the tourist destination - producers (agriculture, fishing), processing companies (dairies, olives, mills, wineries), tourism and hospitality sectors (restaurants, specialized accommodation, gastronomic activities), retail sector, trade and even the knowledge sector.

The importance of trade in these products can be seen in the data of the European Commission, which states that the value of wholesale trade in protected products in 2007 amounted to 14.2 billion euros, including 820 products, while in 2019 the number of protected products is 1,459 (wec.europa.eu/agriculture/quality/door/list.html). The development of the 
region in Serbia depends on the geographical position, which in most cases is the cause of functional isolation concerning economic centers, which often results in slower development flows (Lampic \& Potocnik-Slavic, 2007). Accordingly, Dogan \& Gokovali, (2012) state that the system of a geographical indication of origin itself provides small producers from rural areas with better product placement, a better price in differentiating their product from other similar or the same ones. Emphasizing that the demand for traditional products with a geographical indication is growing worldwide.

The promotion of products with protected origin has a positive impact on the agricultural and food sector. So that the benefits that the economy has by geographical protection of products stand out as follows:

- maintenance and/or increase of income and number of employees in different phases of the production process (production, processing, distribution);

- the possibility for locals to stay and live in the production area;

- maintaining a tradition in agricultural practice that contributes to the preservation of the environment, biodiversity, and land;

- preservation of traditional recipes and production systems; as well as maintaining local tradition and culture (Vandecandelaere et al., 2010).

There is a growing consumer interest in traditional and regional products from the countries of the European Union. They represent products that are decorated with signs and certificates that confirm the high quality of the food product, the unique character, origin from certain regions or production by traditional methods in accordance with culinary heritage (recipes are passed down from generation to generation). Their registrations are regulated by numerous regulations and statutes intended to protect food from counterfeiting and unjustified appropriation (Wojciechowska-Solis, 2019). Despite certain shortcomings in certain sectors of the Republic of Serbia, there are many traditional agricultural and food products, as well as gastronomic products, which can be placed on the tourist market. The participation of all catering and tourism entities in the region is necessary for the process of creation, design, and development (Kalenjuk et al., 2010).

The diversity of the region in the production of traditional agricultural and food products and dishes is reflected in the fact that the production, preparation, and marketing of such products is of interest to foreign tourists. Such products are the fruit of producers engaged in the production of high-quality products with protected quality, prepared from their raw materials, in the traditional way such as dairy products, meat products, fish products, fruits, alcoholic products, grape products, special and indigenous wines. The need to protect high-quality products with a geographical indication of origin appears as a form of protection against possible commercial fraud, since such products are associated with a higher retail price and bring more financial benefits to producers compared to other similar products (Danezis et al., 2016). The connection between production and territory is the essence of defining a quality product that is attributed to a certain geographical area from which it originates. As such, these products must meet three basic criteria:

- $\quad$ specific use of local resources in production processes;

- historical connection with the territory - including the tradition of production and consumption;

- the collective dimension of localized know-how (Belletti et al., 2017).

Also, traditional agricultural and food products can include products of producers engaged in the production and processing of "ecological" products, "healthy" food, and other products. The production of authentic agri-food products may include the production of meat, milk, eggs, and their products, the cultivation of fruits and vegetables in a particular territory, confectionery, production and processing of mushrooms, game (Rodojka et al., 2011), and other indigenous products characteristic for Serbia, authentic dishes and drinks (Banjac et al., 2016). In the 
European Union, the production of protected products is increasingly the focus for the use of geographical indications, because such products differ in the international market, on one hand improving the competitiveness and profitability, while on the other hand there is growth in consumer interest in quality and traditional products - especially produce and foodstuffs with specific, recognizable characteristics which are related to the geographical origin and by the method of production (Hajdukiewicz, 2014).

\section{Methodology}

The research was conducted based on data available to the Institute for the Protection of Intellectual Property of the Republic of Serbia. Serbia (Republic of Serbia The Intellectual Property Office, 2018) and appropriate documentation on protected products (Protection Study). The paper reviews the products that are protected until the beginning of 2020. Methods of analysis, synthesis, and comparison were used in the research. For the needs of the analysis of the collected data, the following geographical regions on the territory of the Republic of Serbia were considered in the research: Vojvodina, Eastern region, Sumadija, Western region and Southern region. For administrative reasons, the research did not include the regions of Kosovo and Metohija and Belgrade, as well as protected non-food products. Belgrade, as the main tourist center, represents consumers and distributors of all protected agricultural and food products in the region, but the number of products in this area is negligible, as in the territory of Kosovo and Metohija.

\section{Results and Discussion}

\subsection{Analysis of protected products in Vojvodina}

Vojvodina, the northern part of Serbia is a region that represents a large food producer. Observing the number of protected products in Vojvodina until 2016, which is regionally shown in Figure 1, we can see a small representation of products in Banat (eastern part of the region), southern Srem (gravity zone near Belgrade), and northern Backa (region towards the border with Hungary). Until 2020, 2 more products are declared protected on the territory of Vojvodina, which is exactly 19 products with a designation of origin, which makes a share of $34.55 \%$, on the territory of the of Vojvodina in Serbia.

Figure 1. Protected Products of Vojvodina

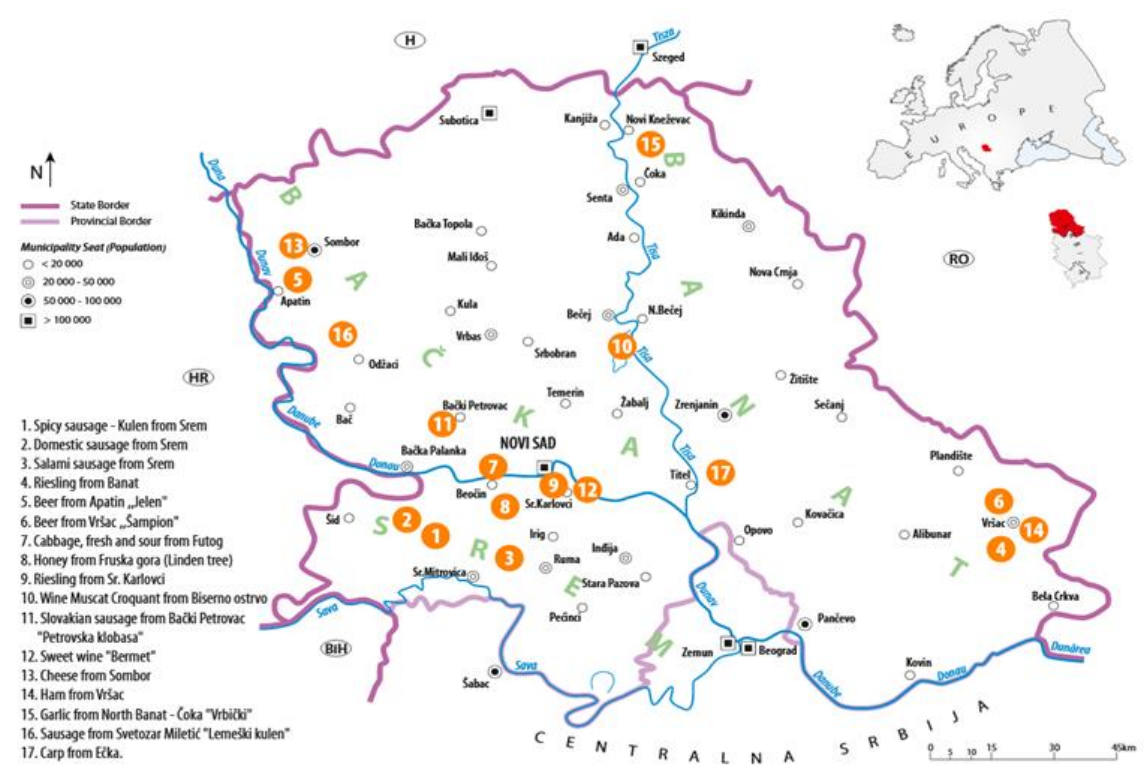


(Source: Banjac et al., 2016)

The inventory list of protected products that can and should be found in the offer of catering and tourist facilities in Vojvodina includes the following products from the group of meat products:

1. Kulen from Lemeš (spicy sausage); place: Svetozar Miletić, has a name of origin since 2014;

2. Ham from Vršac (ham with a characteristic smell and taste); place: Vršac, has a name of origin since 2014;

3. Kulen from Srem (spicy sausage prepared from pork in a natural intestine); place: Šid, has a name of origin since 1992;

4. Homemade sausage from Srem (sausage prepared from pork with a characteristic taste); place: Šid, has a name of origin since 1996;

5. Salami from Srem (sausage prepared from pork and beef with a characteristic appearance and taste); place: Šid, has a name of origin since 1996;

6. Sausage from Petrovac (sausage with a pleasant smell, smoke, and aroma of a mature product); place: Bački Petrovac, has a name of origin since 2007;

7. Ečan carp (carp with special sensory and nutritional characteristics); place: Ečka, has a geographical indication since 2013;

8. Cheese from Sombor (sheep cheese in a wooden can); place: Sombor, has a name of origin since 2013;

9. Cabbage from Futog (fresh and sauerkraut); place: Futog, has a origin name since 2008;

10. Fruška Gora linden honey (linden honey from the slopes of Fruška Gora); place: mountain Fruška Gora, has a name of origin since 2011;

11. Carrot from Begeč (carrot of characteristic color, sweetness, and texture); place: Begeč, has a geographical indication since 2017;

12. Vrbički garlic (garlic of special properties and qualities); place: Choka, has a name of origin since 2016;

13. Deliblatski honey (honey with special nutritional and sensory characteristics); place: Deliblatska Peščara, waiting for a geographical indication from 2018;

as well as drinks:

14. Banat Riesling (characteristic table white wine); place:Vršac, has a origin name since 1998;

15. Champion Beer (light beer of typical taste); place: Vršac, has a geographical indication since 1998;

16. Beer Deer (light beer); place: Apatin, has a geographical indication since 2002;

17. Muscat Krokan wine from the Pearl Island (wine of harmonious taste); place: Novi Bečaj, has a name of origin since 2003;

18. Bermet wine (dessert wine with the addition of spices and herbs); place: Sremski Karlovci, has a name of origin since 2007;

19. Riesling from Karlovac (quality white dry wine); place: mountain Fruška Gora, has a name of origin since 2008 .

\subsection{Analysis of protected products of the Western region}

Western region R. Due to its specific geographical position, Serbia has a large number of products with the protected origin. In the territory of the western region, 11 products of agricultural and food origin are protected, which makes a share of $20 \%$ of protected products on the territory of the state. Among the protected products that may be of importance in the offer to domestic and foreign visitors to the region are the following meat products: 
1. Tobacco greaves from Valjevo (greaves of characteristic appearance made from pig meat); place: Valjevo, has a name of origin since 2007;

2. Beef prosciutto from Užice (smoked beef leg, characteristic smell, and taste from the area of the mountain Zlatibor); place: Čajetina, has a name of origin since 1996;

3. Pork prosciutto from Užice (smoked pork prosciutto on beech wood from the area of the mountain Zlatibor); place: Čajetina, has a name of origin since 1996;

4. Pork bacon from Užice (smoked pork bacon from the slopes of the mountain Zlatibor); place: Čajetina, has a name of origin since 1996;

5. Lamb from Sjenica (autochthonous variety of sheep from Sjenica-Pešter Plateau); place: Sjenica-Pešter Plateau, has a name of origin since 2013;

6. Litter from Sjenica; (dry smoked mutton); place: Sjenica, has a geographical indication since 2017;

Range of dairy products:

7. Cheese from Zlatar (full-fat soft cheese in cow's milk brine); place: mountain Zlatar, has a name of origin since 2013;

8. Sheep cheese from Sjenica (soft full-fat cheese made from sheep's milk in brine); place: Sjenica-Pešter Plateau, has a name of origin since 2012;

9. Cow's cheese from Sjenica (soft full-fat cow's cheese in brine from raw cow's milk); place: Sjenica-Pešter Plateau, has a name of origin since 2014; as well as:

10. Potatoes from Ivanjica (autochthonous potato variety, characterized by the place of cultivation); place: Ivanjica, has a geographical indication since 2018;

11. Raspberry from Arilje (raspberry characterized by the color that varies from light to dark red); place: Arilje, has a name of origin since 2009.

\subsection{Analysis of protected products in Šumadija}

Šumadija, as the central part of Serbia, is a very important region. The analysis of protected products revealed that there are only 4 protected food products on the territory of Sumadija, which amounts to a share of $7.27 \%$ in the territory of the Republic of Serbia, which includes:

1. Honey from the Kačer region (flower honey with a characteristic taste and aroma); place: Kacer region, has a geographical indication since 2011;

2. Rose wine from Jagodina (table dry rosé wines from autochthonous grape varieties); place: Jagodina, has a geographical indication since 1998;

3. Water Vrnjci (mineral water from the spring Vrnjačka Banja, known since the Roman conquest of the Balkans); place: Vrnjačka Banja, has a geographical indication since 2002;

4. Mineral water Knjaz Miloš (mineral water from Bukovačka Banja); place: Arandjelovac, has a geographical indication since 2003.

The absence of food products based on meat, milk, fruits, vegetables, and processed products can be stated here.

\subsection{Analysis of protected products of the Eastern region}

The Eastern region as a set of different cultures has always been very specific. Based on the conducted research, it was found that 10 food products are protected on the territory of Eastern Serbia, which makes $18.18 \%$ of protected products on the gastro-tourist map of the country, and these are from the group of dairy products:

1. Sheep cheese from Homolje (sheep cheese in brine recognizable by a specific combination of local and natural characteristics); place: Homolje, has a name of origin since 1996;

2. Goat cheese from Homolje (goat cheese in brine recognizable by a specific combination of local natural characteristics); place: Homolje, has a name of origin since 1996; 
3. Cow cheese from Homolje (cow cheese in brine recognizable by a specific combination of local, natural characteristics); place: Homolje, has a name of origin since 1996;

4. Cheese from Krivi Vir (cheese with a moderately sharp smell and taste, reminiscent of the taste and smell of walnuts); place: Zaječar district, has a name of origin since 1996;

as well as:

5. Sausage from Požarevac (sausage made from beef and pork); place: Danube region, has a name of origin since 1996;

6. Caviar from Kladovo (made from cod, sturgeon, trout, and sturgeon); place: Kladovo, has a name of origin since 2000;

7. Honey from Djerdap (acacia linden and meadow honey, with plant and fruit aromas and vanilla aroma); place: Djerdap, has a geographical indication since 2016;

8. Honey from Homolje (acacia meadow honey light to dark ocher yellow to amber); place: Homolje, has a name of origin since 2008;

9. Tea from Rtanje (tea from the plant saturea montana with a pleasant and specific smell); place: mountain Rtanj, has a name of origin since 1996.

10. Mineral water Duboka (drinking water from the slopes of the Homolje mountains); place: Kučevo, has a geographical indication since 2003;

From the mentioned group, caviar from Kladovo has a special significance in the offer due to its specificity.

\subsection{Analysis of protected products of the Southern region}

The southern part of Serbia has always been a combination of a traditional table that dates back to the time of the Turks in the Balkans, which can certainly be seen based on the present gastronomic offer. The analysis of protected products in the southern region revealed that 11 products with a designation of origin are protected in this part of Serbia, which makes a share of $20 \%$ of protected products in the territory. Protected products include the following dairy products:

1. Cow's cheese from Svrljig (cow's milk cheese with characteristic properties); place: Svrljig, has a name of origin since 2017;

2. Cheese from Svrljig (cow's cheese with a characteristic smell and taste, yellow color): place: Svrljig, has a name of origin since 2008;

3. Belmush from Svrljig (a dish that is traditionally prepared from young cheese and flour); place: Svrljig, has a name of origin since 2010;

4. Cow's milk cheese from Pirot (cow's milk cheese, pleasant slightly sour taste); place: Pirot, has a name of origin since 2012;

5. Cheese from Stara Planina (semi-hard fatty steamed cheese made from king's and sheep's milk from Stara Planina); place: Pirot, Dimitrovgrad, has a name of origin since 2010;

as well as:

6. Cherry Cloud (an indigenous type of cherry); place: Oblačina, Merošina, has a name of origin since 2015 ;

7. Grilled meat from Leskovac (meat mass for kebabs and burgers, prepared from several types of meat); place: Leskovac, has a name of origin since 2007;

8. Homemade ajvar from Leskovac; (winter salad of fleshy varieties of peppers); place: Leskovac, has a name of origin since 2011;

9. Honey from Vlasina (honey from Vlasina plateau); place: Vlasina, has a geographical indication since 2017;

10. Frying from Leskovac (traditional product prepared by melting and squeezing fat); place: Leskovac, has a geographical indication since 2018;

11. Aqua Heba mineral water (mineral water, pleasant taste); place: Bujanovac, has a geographical indication since 2003. 


\subsection{Analysis of the distribution of protected products as significant actors in tourism development}

The distribution of products with protected origin is an important factor in the promotion and decentralization of the region. Adequate protection and the use of traditional products create favorable conditions for the promotion of the region from which the product originates. Such food is also an aid for attracting tourists oriented towards gastronomic tourism, as well as all other selective forms of tourism, in which food is an important factor. Observing the data obtained by inspecting protected products by regions whose total values are shown in Graph 1 , the regional distribution of protected products in the territory of the Republic of Serbia was stated.

Based on the collected data, it can be noticed that the largest number of protected products is owned by the northern region of the Autonomous Province of Vojvodina with a share of as high as $34.55 \%$ or 19 food products of the total number of protected products in the country. The products of all groups are introduced here and as such, they are representative of the catering and tourist offer. The western and southern regions have an equal share of $20 \%$, ie 11 products with the protected origin, which are also not negligible values. While the eastern region participates with a share of $18.18 \%$ or 10 protected products, and Šumadija, as a central region, is the area with the lowest number of protected products, with a share of only $7.27 \%$ with only 4 products with the protected origin. Considering the total agricultural, food, and gastronomic potentials, the number of these products could be significantly higher. And thus, the economic effects of the region and the state.

Graph 1. Share of protected products in Serbia

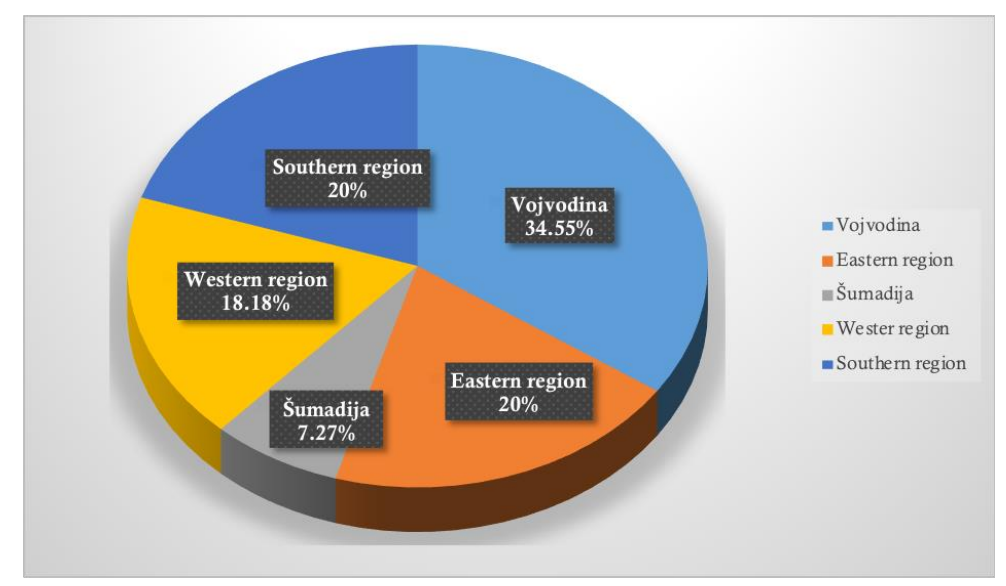

\section{Conclusions}

Products of protected origin represent the preservation of national identity and are extremely important for the authentic gastro tourism offer. Serbia, like any other country, has products that, due to their authenticity, have a mark of origin. By placing them on the market in an adequate way, they contribute to the development of the country and the region. Based on the conducted research and consulting the representative scientific and professional literature in the field of product protection and tourism, as an important economic player, it is concluded that Vojvodina stands out as the region with the largest number of protected products with a share of $34.55 \%$ of food products. In the second place are the western region and the southern region with a share of $20 \%$ of food products. Followed by the eastern region with a share of $18.18 \%$ of food products. The region with the least protected products is Šumadija with a share of only $7.27 \%$, which is certainly a devastating fact given that it is the region with the greatest potential for attracting tourists and promoting products with the protected origin. 


\section{Acknowledgment and funding}

The authors acknowledge financial support of the Ministry of Education, Science and Technological Development of the Republic of Serbia and the Faculty of Science, University of Novi Sad, Grant No. III 46009; Provincial Project for Higher Education and Scientific Research, No. 142-451-3172/2020-01: the "The influence of local farmers on the construction of the identity of the catering and tourist product of Vojvodina".

\section{Conflicts of Interest}

The authors declare no conflict of interest.

\section{References}

Agostino, M., \& Trivieri, F. (2014). Geographical Indication and Wine Exports. An Empirical Investigation Considering the Major European Producers. Food Policy, 46, 22-36. https://doi.org/10.1016/j.foodpol.2014.02.002

Anton, P., Boris, K., \& Branka, M. (2016). Impact of Promotional Activities on the Development of Autochtonous Food Product Market. Ekonomika, Journal for Economis Theory and Practice and Social, 62(4), 86-94. https://doi.org/10.22004/ag.econ.290328

Baldacchino, G. (2015). Feeding the Rural Tourism Strategy? Food and Notions of Place and Identity. Scandinavian Journal of Hospitality and Tourism, 15(1-2), 223-238. https://doi.org/10.1080/15022250.2015.1006390

Banjac, M., Kalenjuk, B., Tesanovic, D., Gagic, S., \& Cvetkovic, B. (2016). Gastronomic Tourism in Rural Areas of Vojvodina (Serbia). Turizam, 20(4), 180-191. https://doi.org/10.5937/turizam1604180b

Banjac, M., Kalenjuk, B., Tesanovic, D., Gagic, S., \& Cvetkovic, B. (2012). Products With Origine and Their Significance for the Pevelopment of Gastronomic Tourism in Vojvodina. Trends and Challenges in Food Tehnology, Nutrition, Hospitality and Tourism. 2nd International Professional Conference Proccedings, November 16th-18th, 349-358.

Belletti, G., Marescotti, A., \& Brazzini, A. (2017). Old World Case Study: The Role of Protected Geographical Indications to Foster Rural Development Dynamics: The Case of Sorana Bean PGI (pp. 253-276). https://doi.org/10.1007/978-3-319-53073-4_10

Bojana, K., Dragan, T., Snježana, G., \& Marija, K. (2014). Importance of Food With Protected Origin and Attitudes of Employees Towards the Development of Gastronomic Tourism. Tourism Education Studies and Practice, 3(3), 98-107. https://doi.org/10.13187/tesp.2014.3.98

Brown, L., \& Paszkiewicz, I. (2017). The Role of Food in The Polish Migrant Adjustment Journey. Appetite, 109, 57-65. https://doi.org/10.1016/j.appet.2016.11.024

Bryła, P. (2017). The Perception of EU Quality Signs for Origin and Organic Food Products Among Polish Consumers. Quality Assurance and Safety of Crops \& Foods, 9(3), 345-355. https://doi.org/10.3920/QAS2016.1038

Cairns, G. (2013). Evolutions in Food Marketing, Quantifying the Impact, and Policy Implications. Appetite, 62, 194-197. https://doi.org/10.1016/j.appet.2012.07.016

Cei, L., Stefani, G., Defrancesco, E., \& Lombardi, G. V. (2018). Geographical Indications: A First Assessment of The Impact on Rural Development in Italian NUTS3 Regions. Land Use Policy, 75(September), 620-630. https://doi.org/10.1016/j.landusepol.2018.01.023

Chilla, T., Fink, B., Balling, R., Reitmeier, S., \& Schober, K. (2020). The EU Food Label 'Protected Geographical Indication': Economic Implications and Their Spatial Dimension. Sustainability, 12(14), 5503. https://doi.org/10.3390/su12145503

Conneely, R., \& Mahon, M. (2015). Protected Geographical Indications: Institutional Roles in Food Systems Governance and Rural Development. Geoforum, 60, 14-21. https://doi.org/10.1016/j.geoforum.2015.01.004

Danezis, G. P., Tsagkaris, A. S., Camin, F., Brusic, V., \& Georgiou, C. A. (2016). Food Authentication: Techniques, Trends \& Emerging Approaches. TrAC - Trends in Analytical Chemistry, 85, 123-132. https://doi.org/10.1016/j.trac.2016.02.026

Deselnicu, O. C., Costanigro, M., McFadden, Souza-Monteiro, D. M., \& Thilmany, D. (2013). 
A Meta-Analysis of Geographical Indication Food Valuation Studies: What Drives the Premium for Origin-Based Labels? Agricultural and Resource Economics, 38(2), 204-219.

Dogan, B., \& Gokovali, U. (2012). Geographical Indications: The Aspects of Rural Development and Marketing Through the Traditional Products. Procedia - Social and Behavioral Sciences, 62, 761-765. https://doi.org/10.1016/j.sbspro.2012.09.128

Fernández-Ferrín, P., Bande, B., Galán-Ladero, M. M., Martín-Consuegra, D., Díaz, E., \& Castro-González, S. (2019). Geographical Indication Food Products and Ethnocentric Tendencies: The Importance of Proximity, Tradition, and Ethnicity. Journal of Cleaner Production, 241, 118210. https://doi.org/10.1016/j.jclepro.2019.118210

Firdaus, F. (2018). Potency of Integrated Cultural Tourism Development at Maninjau Lake Area, West Sumatera. Mimbar: Jurnal Sosial Dan Pembangunan, 34(1), 72-82. https://doi.org/10.29313/mimbar.v34i1.3113.72-82

Fusté-Forné, F. (2020). Developing Cheese Tourism: a Local-based Perspective From Valle de Roncal (Navarra, Spain). Journal of Ethnic Foods, 7(1), 26. https://doi.org/10.1186/s42779020-00064-2

Hajdukiewicz, A. (2014). European Union Agri-Food Quality Schemes For the Protection and Promotion of Geographical Indications and Traditional Specialities: an Economic Perspective. Folia Horticulturae, 26(1), 3-17. https://doi.org/10.2478/fhort-2014-0001

Hall, C. M., \& Sharples, L. (2003). The Consumption of Experiences or the Experience of Consumption? An Introduction to The Tourism of Taste. Food Tourism around the World: Development, Management and Markets, 1-3.

Jurinčič, I., Gačnik, A., Kerma, S., Balažič, G., \& Ilak, A. S. (2015). Malvazija Istarska-Proizvod sa Geografskim Porijeklom i njen Značaj za Razvoj Prekograničnog Brenda u Istri. 50 Th Croatian and 10 ThInternational Symposium on Agriculture . Croatia, 164-168.

Kalenjuk, B., Vulić, G., \& Tešanović, D. (2010). Positioning of Protected Slovenian Gastronomic Products in Tourism. Zbornik Radova Departmana Za Geografiju, Turizam i Hotelijerstvo, 39, 232 $-247$.

Katerinopoulou, K., Kontogeorgos, A., Salmas, C. E., Patakas, A., \& Ladavos, A. (2020). Geographical Origin Authentication of Agri-Food Products: A Review. Foods, 9(4), 489. https://doi.org/10.3390/foods9040489

Lampic, B., \& Potocnik-Slavic, I. (2007). Demographic Vitality and Human Resources as Important Factors for Rural Areas Development. Glasnik Srpskog Geografskog Drustva, 87(2), 103-114. https://doi.org/10.2298/GSGD0702103L

Likoudis, Z., Sdrali, D., Costarelli, V., \& Apostolopoulos, C. (2016). Consumers' Intention to Buy Protected Designation of Origin and Protected Geographical Indication Foodstuffs: the Case of Greece. International Journal of Consumer Studies, 40(3), 283-289. https://doi.org/10.1111/ijcs.12253

Lombardo, R. (2015). Typical Products and Cultural Identity: The Cases of Tripe of Florence and Pistachio of Bronte [Prodotti Tipici e Identita Culturale: i Casi del Lampredetto di Firenze e del Pistacchio di Bronte]. Humanities, 4(7).

Long, L. M. (2004). Learning to Listen to the Food Voice. Food, Culture \& Society, 7(1), 118-122. https://doi.org/10.2752/155280104786578067

Marina, J.-S., Jovicevic, P., \& Novakovic, S. (2016). Appellations of Geographical Origin as a Generator of National Competitiveness. Ekonomika Poljoprivrede, 63(2), 567-583. https://doi.org/10.5937/ekoPolj1602567J

Neciunskas, P., Tomaseviciute, L., Kazlauske, D., Gineikiene, J., \& Kazlauskaite, R. (2017). Uniqueness Perception And Willingness To Buy Protected Geographical Origin Versus Doppelgaenger Brands. Organizations and Markets in Emerging Economies, 8(2), 16.

Oliinyk, K., Baranovych, M., \& Akhtimirova, M. (2018). Protection of EU Geographical Indications in Ukraine. EU-Ukraine Association Agreement and Other Available Tools, 13(3), 241-249.

Prokopović, B., \& Prokopović, T. (2011). Brand as our destiny. Ekonomika: International Journal for Economic Theory and Practice and Social Issues, 1, 108-114.

Republic of Serbia The Intellectual Property Office. (2018). Institute for the Protection of Intellectual Property of the Republic of Serbia. Republic of Serbia The Intellectual Property Office. 
Rodojka, M., Slobodan, C., \& Blazenka, P. (2011). Small And Medium Enterprises As Factors In Reducing Poverty In Rural Communities Serbian. Economics of Agriculture, 58(1), 121 131. https://doi.org/10.22004/ag.econ.244827

Roselli, L., Giannoccaro, G., Carlucci, D., \& De Gennaro, B. (2018). EU quality labels in the Italian olive oil market: How much overlap is there between geographical indication and organic production? Journal of Food Products Marketing, 24(6), 784-801. https://doi.org/10.1080/10454446.2017.1413473

Santeramo, F. G., Carlucci, D., De Devitiis, B., Seccia, A., Stasi, A., Viscecchia, R., \& Nardone, G. (2018). Emerging trends in European food, diets and food industry. Food Research International, 104, 39-47. https://doi.org/10.1016/j.foodres.2017.10.039

Tešanović, D., \& Koprivica, M. (2007). Influence of Quality Definition of Regional Gastronomic Products on Formation of Touristic Offer of Serbia. Recognisable National Gastronomy-Tourist Potential, 217-223.

Ucuncuoglu, D. (2020). Geographical Indications and Designations of Origin linked Agricultural Products: Current Statistics from Turkey. Turkish Journal of Agriculture - Food Science and Technology, 8(4), 957-959. https://doi.org/10.24925/turjaf.v8i4.957-959.3214

Vandecandelaere, E., Arfini, F., Belletti, G., \& Marescotti, A. (2010). Linking People, Places and Products: A Guide for Promoting Quality Linked to Geographical Origin and Sustainable Geographical Indications (Second). Food and Agriculture Organization of the United Nation.

Wilson, J. S., Petino, G., \& Knudsen, D. C. (2018). Geographic Context of the Green Pistachio of Bronte, a Protected Designation of Origin Product. Journal of Maps, 14(2), 144-150. https://doi.org/10.1080/17445647.2018.1438318

Wojciechowska-Solis, J. (2019). The Importance of Regional Products in the Promotion of Rural Tourism. Przedsiębiorczość i Zarzadzanie, XX(1), 137-147.

Word Tourism Organization UNWTO. (2012). Global Report on Food Tourism. In Journal of Chemical Information and Modeling (Vol. 53, Issue 9). Global Report on Food Tourism.

Word Tourism Organization UNWTO. (2019). Guidelines for the Development of Gastronomy Tourism. In Guidelines for the Development of Gastronomy Tourism. Word Tourism Organization. https://doi.org/10.18111/9789284420957

Zarić, V., Bogdanov, N., \& Vasiljevic. (2012). Traditional products of the Republic of Serbia. Tradition despite the Crisis - Is It Possible?, 47-58. 